\title{
The Role of Autumn Infections in the Progression of Fire Blight Symptoms in Perennial Pear Branches
}

\author{
D. Blachinsky and D. Shtienberg, Department of Plant Pathology, ARO, Volcani Center, Bet Dagan 50250; \\ D. Oppenheim and M. Zilberstaine, Extension Service, Ministry of Agriculture, Bet Dagan 50250; S. Levi, \\ G.O.F.R. Central, Hadera; and E. Zamski and O. Shoseyov, Institute of Plant Science and Genetics, Faculty of Ag- \\ ricultural Food and Environmental Quality Sciences, Hebrew University of Jerusalem, Rehovot 70600, Israel
}

\begin{abstract}
ABTRACT
Blachinsky, D., Shtienberg, D., Oppenheim, D., Zilberstaine, M., Levi, S., Zamski, E., and Shoseyov, O. 2003. The role of autumn infections in the progression of fire blight symptoms in perennial pear branches. Plant Dis. 87:1077-1082.

The role of autumn infections in the progression of fire blight (caused by Erwinia amylovora) symptoms in perennial pear branches was studied in orchard-grown trees in Israel. The extent of symptom progression and the final length of fire blight cankers in perennial branches were variably affected by the vigor of the trees and the season of infection. Following spring infections, when all trees supported active shoot growth, fire blight symptoms progressed more rapidly and to longer distances in trees that exhibited high vigor (i.e., with numerous annual shoots on most terminal branches) than in low-vigor trees (i.e., few or no annual shoots on terminal branches). Irrespective of the vigor of the trees, the progression of fire blight symptoms in perennial branches ceased between mid-May and mid-July, and only a small proportion ( 0 to $14.2 \%$ ) of the infections had invaded main limbs or trunks of trees. Progression of fire blight symptoms following autumn infections was related to the preceding summer (August to November) shoot regrowth: in trees in which the shoots did not restore their growth in the summer, the rate of symptom progression in perennial branches was higher in trees with a low vigor than in those with a high vigor, whereas for those with summer regrowth the relationship between rates of symptom expression was reversed. Irrespective of the vigor group and of whether there was summer regrowth, symptoms in perennial branches continued to progress through the winter until the following spring. Most of the autumn infections (50 to 78.5\%) that developed in susceptible trees had invaded main limbs or trunks of trees. The results of this study indicate that factors related to host phenology and physiology, rather than factors related to environmental influences (such as temperature), govern the extent, rate, and duration of fire blight progression in perennial pear branches. Furthermore, it turned out that autumn infections play a substantial role in fire blight epidemiology in Israel.
\end{abstract}

Fire blight, caused by the bacterium $\mathrm{Er}$ winia amylovora, is the most destructive disease of pears and other pome fruit trees worldwide. The pathogen infects all plant parts: leaves, blossoms, fruit, shoots, limbs, and trunks. Initial inoculum may originate either from active cankers or from bacteria that colonize the plant tissues epiphytically or endophytically (23). Primary infection usually takes place in blossoms and develops into blossom blight, but in some years it involves shoots rather than blossoms. Wind and rain, together with warm, humid weather during bloom, favor the development of severe blossom blight $(8,16,18,21)$.

E. amylovora may affect tree production in several ways. Since diseased blossom clusters do not produce fruit, the current-

Corresponding author: D. Blachinsky E-mail: daphnabl@volcani.agri.gov.il

Accepted for publication 5 April 2003.

Publication no. D-2003-0701-01R

(C) 2003 The American Phytopathological Society ennial tissues, tree vigor, and phenological stage of the host at which infection occurred. Many researchers have noted that rate of symptom progression is related to age of the tissue. Rapidly growing, succulent shoots are the most susceptible; young tissues ( 2 to 5 years old) are somewhat less susceptible; and the disease seldom progresses in mature ( $>30$ years old) branches $(11,13,19,22)$. The basis for this apparent resistance of older tissues is not known, despite the fact that the pathogen has been occasionally isolated from presumably noninfected tissues (20). However, the age of individual branches is not the only factor governing rate of symptom progression, which may vary markedly among branches of the same age. Suleman (17) indicated that when blossoms on young apple shoots are infected, the pathogen occasionally invades the supporting older branch, producing a canker that, in some instances, progresses to additional branches. However, when blossoms on older, mature branches are infected, necrotic symptoms rarely invade the supporting branches. Similarly, Crosse et al. (5) reported that apple trees supporting vigorous shoot growth are especially susceptible to disease progression. In most cases, progression of the pathogen in perennial branches ceases during mid- to late summer, when daily maximum temperatures exceed $30^{\circ} \mathrm{C}$ and vegetative shoot growth slows. Suleman (17) and Beer and Norelli (1) noted that, in apple trees, canker margins that had previously become determinate undergo some additional expansion in early fall, although they gave no explanation for this renewed activity.

The most common cultivars in Israeli pear orchards are 'Spadona', 'Costia', and 'Spadochina', which are grafted on quince rootstock. Trees may vary markedly in their vigor, even in well-maintained orchards; whereas some exhibit low vigor (i.e., few or no annual shoots on terminal branches), others exhibit high vigor (i.e., numerous annual shoots on most terminal branches). Tree vigor varies among orchards, but variation is also common among trees in the same orchard. Factors governing the vigor of trees reflect genotypic (e.g., cultivar characteristics), cultural (e.g., stock and cultivar fitness, intermittently, soil type), production (e.g., irrigation, fertilization, pruning), and envi- 
ronmental (e.g., temperature, precipitation) influences. The vigor of individual trees may change from season to season and sometimes even within the same season. For example, nitrogen fertilization or massive pruning would immediately result in excessive shoot growth and could shift trees from low to high vigor.

Blooming and vegetative growth occur in Israel in the spring (March to April), after the termination of winter dormancy. However, occasionally, excessive shoot regrowth may also occur after harvesting, in the late summer and autumn (August to October). Similarly, a second blooming period may occur during September to November. Trees that restore their regrowth in the summer usually do not bloom in the coming autumn. Summer shoot regrowth and autumn blooming is not uniform across trees and orchards as in the spring, and the autumn blooms differ from the late-spring rat-tail blooms. Autumn blooming occur primarily in orchards or individual trees that were exposed to stress conditions (mainly drought) after the fruit harvest. As the host tissue most susceptible to infection is the blossom, fire blight infections may occur in Israel in both spring and autumn. Occurrence of autumn infections was first reported in Israel in 1998 (9). However, the significance of autumn blossom infections is not yet clear. It is not known if these infections invade the perennial branches, if the pathogen continues to progress during winter in dormant trees, or to what extent autumn infections serve as a source of initial inoculum the following spring. Observations made in pear orchards in recent years suggest that autumn infections play a substantial role in E. amylovora epidemiology in Israel. In the present study, we examined the roles of tree vigor (low versus high) and of the season when infections took place (spring versus autumn) in the progression of fire blight symptoms in perennial pear branches.

\section{MATERIALS AND METHODS}

During 1999 to 2002, trials and observations were conducted in pear orchards located at Shpheia (Samaria region, central Israel) and Khula Experimental Station (Khula Valley, northern Israel). In these trials, the effects of various factors on the progression of fire blight symptoms in perennial branches of trees were examined. The orchards were planted during 1990 to 1992, and each comprised 300 to 500 trees. The main cultivar in both orchards was Spadona, which is highly susceptible to $E$. amylovora. Trees were cultivated (i.e., irrigated, fertilized, pruned, etc.) and maintained (i.e., weed and pest control, etc.) as in most commercial pear orchards in Israel. Irrigation was applied via a drip system, starting when soil moisture was below the water capacity level (as determined by analysis of soil samples). The exact date was dependent on winter rainfall but usually occurred between mid-April and early May. Irrigation then continued in 7- to 14day intervals (depending on evaporation rate) until harvest (July to August). Eight to ten thousand cubic meters of water per hectare was applied in each orchard each year. Nevertheless, as commonly happens in commercial orchards, trees in the experimental orchards varied markedly in their vigor. Thus, in each orchard, there were trees with high as well as with low vigor.

Trees were classified to vigor groups as follows. Trees bearing few or no succulent annual shoots on most terminal branches, with annual shoots that were short $(<10$ $\mathrm{cm})$ and thin $(<5 \mathrm{~mm})$, were classified as having low vigor. Those with numerous, long $(>30 \mathrm{~cm})$ and thick $(>10 \mathrm{~mm})$ succulent annual shoots on most terminal branches were classified as having high vigor. For the spring trials, trees were assigned temporarily to vigor groups in May, and corrections were made, if needed, in July. For the autumn trials, all trees were classified in July, and for those with summer regrowth, corrections were made, if needed, in November. The experimental unit used in all experiments was the individual infection in a perennial branch.

Symptom progression in perennial branches following spring infections. The extent of symptom progression in perennial branches following spring infections was examined in two sets of trials. In the first set of trials, symptoms originated from natural infections, and in the other set they originated from artificial inoculations. As pear trees normally sprout in the spring, all trees included in the spring trials supported active shoot growth. Fire blight progression in the perennial branches following natural infections of blossoms was recorded in Shpheia in 1999 and 2002. The observations included 33 and 40 replicates (i.e., individual infections) in the respective years, of which 21 and 30, respectively, were on trees with high vigor; the rest were on trees with low vigor. Fire blight progression in perennial branches following artificial inoculation of annual shoots was recorded in Shpheia (in 2001) and Khula (in 2002). Observations included 25 and 31 replicates, of which 6 and 17 , respectively, were on trees with high vigor; the rest were on trees with low vigor.

Symptom progression on perennial branches was recorded from the appearance of visual symptoms in late March to mid-April. Assessments were performed at 2- to 4-week intervals, until disease progression in the perennial branches had ceased in mid-June to mid-July. At each assessment, the length of the visible fire blight canker in each branch was measured. In some cases, a superficial cut of the bark with a sharp knife assisted in determining the presence of tissue discoloration typical of E. amylovora. The knife was disinfected with $2 \%$ sodium hypochlorite before and after use. As infections progressed from branch to branch (i.e., from a 2-year-old branch to a 3-year-old one, from a 3-year-old to a 4-year-old, etc.), measurements were done separately on each branch, and the number of branches to which the disease had progressed was noted. It was also recorded if the disease had invaded main limbs or trunks.

Symptom progression in perennial branches following autumn infections. Fire blight progression in perennial branches following autumn infections was recorded in four trials. Three trials were conducted in Shpheia (in the autumns of 1999/00, 2000/01, and 2001/02) and one in Khula (in autumn of 2001/02). In the first three trials, shoots did not restore their growth in the summer, but in the fourth trial, trees had active shoot regrowth in August to September. Observations covered 45, 28, 160, and 14 replicates (individual infections) in the respective trials, of which $27,14,126$, and 10 , respectively, were on trees with high vigor and the rest were on trees with low vigor. Symptom progression in perennial branches was recorded as described above, starting soon after the appearance of visible symptoms in November to December and continuing at 2- to 4-week intervals until April of the following year. Measurements were terminated when new spring infections precluded reliable identification of symptoms resulting from autumn infections.

Artificial inoculation and data analysis. Artificial inoculation of individual branches was performed as follows. In each trial, 40 to 200 individual branches were selected and marked with colored, numbered bands; about half of them were placed on trees with low vigor and the rest on trees with high vigor. The number of successful inoculations (i.e., those resulting in fire blight symptoms that progressed to the supporting perennial branch) varied among the experiments, as indicated above. Branches selected for inoculation supported succulent annual shoots and included at least four perennial branches (i.e., a 2-year-old branch, a 3-year-old branch, etc.) connecting to the main limb or trunk of the tree. Up to four branches, each on a separate main limb, were inoculated on each tree. The annual succulent shoot was cut superficially with a sharp knife about 1 to $2 \mathrm{~cm}$ above its growth base from a perennial branch. A drop of bacteria suspension (containing about $10^{8}$ E. amylovora cells per $\mathrm{ml}$ ) was then dripped into the wound. A mixture of $E$. amylovora strains 238 and 249, provided by S. Manulis of the ARO, was used in all inoculations. Both strains are sensitive to oxolinic acid and streptomycin sulfate, bactericides that are commonly used for fire blight management by pear growers in Israel. To improve the likelihood of suc- 
cess, inoculations were performed just before sunset, when ambient temperatures had decreased and relative humidity had increased. Inoculations were performed on 15 April 2001 (Shpheia) and 2 April 2002 (Khula) for the spring experiments, and on 18 November 1999, 10 November 2000, 21 November 2001 (Shpheia), and 18 December 2001 (Khula) for the autumn experiments.

Data were analyzed separately for each sampling date. The cumulative length of fire blight cankers on the various perennial branches was calculated for each infection. Canker lengths were then averaged separately according to the vigor of the trees (i.e., low or high), and the standard error was calculated for each group. In addition, the proportion of infections that had progressed to four or more consecutive branches and had invaded the main limbs or the trunk was calculated; these infections will be referred to as "expanded infections". Differences in the proportion of expanded infections between trees with low and high vigor were determined by means of a $\chi^{2}$ test at $P \leq 0.05$.

Daily minimum and maximum air temperatures for the experimental periods were provided by the National Weather Forecast Service. Temperature was measured by standard weather stations located in the vicinity of the experimental orchards. Daily temperatures were averaged, and the 10-day means are presented in this report.

\section{RESULTS}

Symptom progression in perennial branches following spring infections. Fire blight progression following spring infections was recorded for infections originating from natural blossom infections as well as those from artificial inoculations. In general, the pattern of symptom progression in perennial branches originating from artificial inoculations resembled that of symptoms from natural infections. The rate of symptom progression in perennial branches and the final length of the cankers were higher in trees with high vigor than in those with low vigor. Nevertheless, in both groups, symptom progression was relatively restricted; canker length usually did not exceed $30 \mathrm{~cm}$ (Fig. 1), and infections expanded to the main limbs of the trees in only a few cases (Table 1). Irrespective of the vigor status of trees and the source of infection (natural or artificial), the progression of fire blight symptoms following spring infections on perennial branches ceased in mid-May to midJuly, and none of the infections resumed their expansion subsequently. Temperatures at that time ranged from a minimum of 12 to $18^{\circ} \mathrm{C}$ to a maximum of 25 to $30^{\circ} \mathrm{C}$ (Fig. 1).

Symptom progression in perennial branches following autumn infections. In three of four trials in which fire blight progression was recorded in perennial branches following autumn infections, shoots did not resume growth in the preceding summer; whereas there was active shoot regrowth in the fourth trial. In the first three trials, progression of fire blight symptoms in perennial branches was faster, canker length was longer, and the proportion of infections that invaded main limbs and trunks was higher in trees with low vigor than in those with high vigor. In the fourth trial, in which shoots were actively growing in the preceding summer, the situation was reversed: fire blight symptoms progressed further and significantly more infections invaded main limbs and trunks in trees with high vigor than in
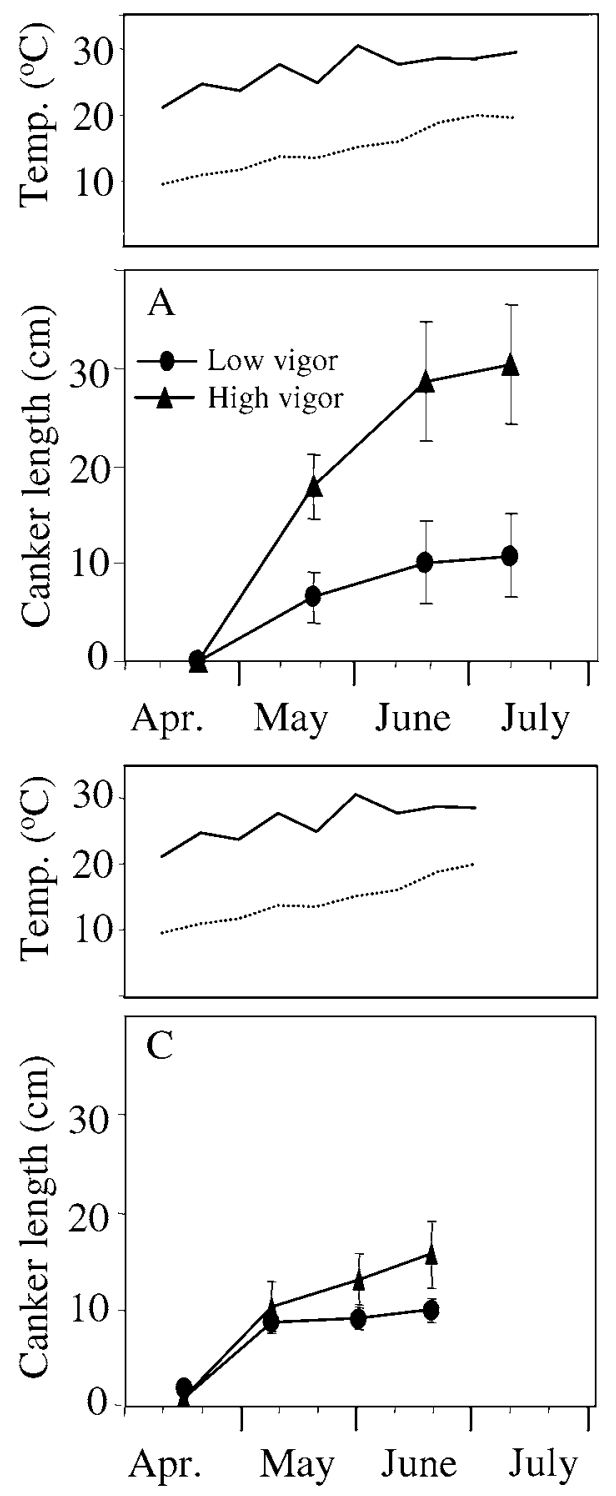

Fig. 1. Effect of the vigor of pear trees on the progression of fire blight symptoms in perennial branches, following spring infections. All trees supported actively growing shoots. A and B, cankers resulted from natural infections of blossoms in Shpheia in 1999 and 2002, respectively; C and D, cankers resulted from artificial inoculation of annual shoots in Shpheia in 2001 and Khula in 2002, respectively. Trees with low vigor: succulent annual shoots did not develop at most terminal branches and the annual shoots that did develop were short $(<10 \mathrm{~cm})$ and thin $(<5 \mathrm{~mm})$. Trees with high vigor: trees that had numerous, long $(>30 \mathrm{~cm})$ and thick $(>10 \mathrm{~mm})$ succulent sprouting annual shoots at most terminal branches. Vertical bars represent standard error for each sampling date. Tenday mean temperatures for experimental periods are included. Solid lines: maximum daily temperatures; dotted lines: minimum daily temperatures.
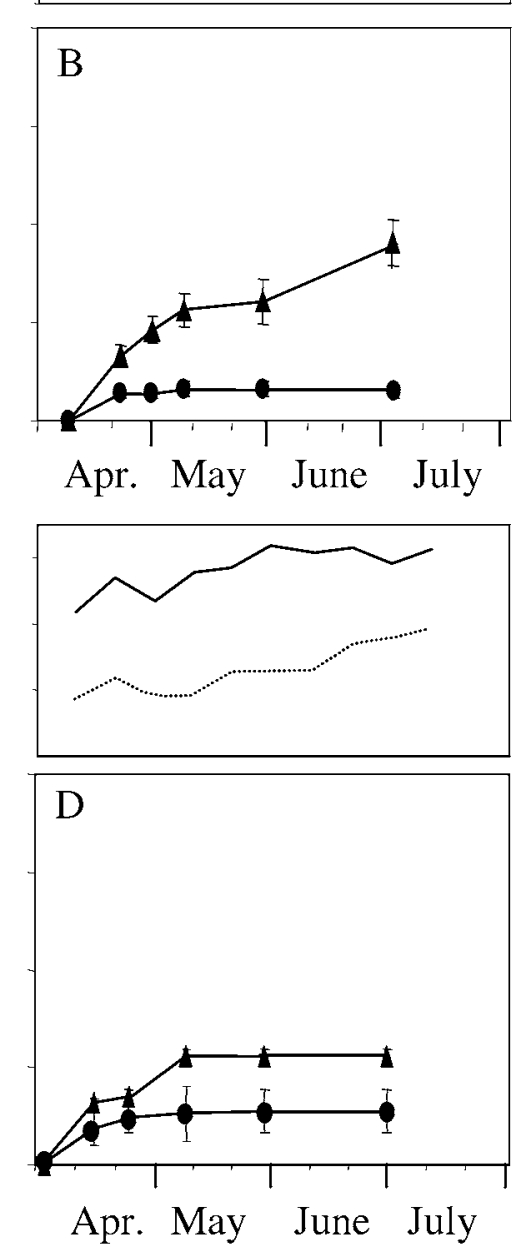

those with low vigor (Fig. 2; Table 1). Irrespective of whether shoots were acvigor group of the trees, symptoms in perennial branches continued to progress durwere terminated. Canker lengths varied among infections, but it was not uncommon for them to exceed $100 \mathrm{~cm}$ (Fig. 2). In
all autumn experiments, more than 50\% of the infections on susceptible trees reached main limbs or trunk (Table 1).

perennial branches exhibited two distinct phases. From the time of inoculation in

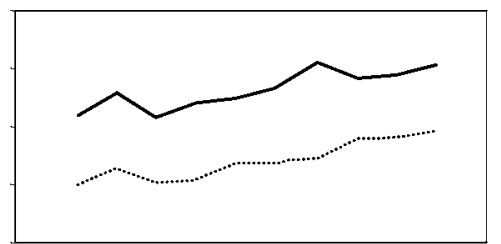

Plant Disease / September 2003

1079 following spring, when measurements 
autumn until mid-January to late February, the rate was relatively slow ( 0.1 to 0.3 $\mathrm{cm} /$ day); then, from mid-January or late February until March or April, progression was much more rapid and reached a rate of up to 1.5 to $2.5 \mathrm{~cm} /$ day (Fig. 2).

During the course of the autumninoculation experiments, air temperatures changed markedly. Temperatures were relatively high in autumn (October and November, minimum 11 to $16^{\circ} \mathrm{C}$, maximum 27 to $30^{\circ} \mathrm{C}$ ), dropped in winter (December to February, minimum 1 to $7^{\circ} \mathrm{C}$, maximum 15 to $17^{\circ} \mathrm{C}$ ), and increased again the following spring (March and April, minimum 8 to $15^{\circ} \mathrm{C}$, maximum 20 to $30^{\circ} \mathrm{C}$ ). Despite the daily and seasonal fluctuations of temperature, progression of fire blight symptoms in perennial branches continued steadily until the plants had bloomed the following season, when the trials were terminated. Moreover, the change from slow progression phase to rapid progression phase occurred in midwinter, when temperatures were at their lowest (Fig. 2).

\section{DISCUSSION}

As for any other pathosystem, the extent of E. amylovora progression in perennial pear branches is governed by interactions between pathogen, host, environment, and activities of the grower. The environment may affect the pathogen directly. While progressing within host tissues, bacteria are protected from most environmental influences (e.g., solar radiation, relative humidity, and fluctuations in wetness). The environmental factor that could have the most pronounced effect on the bacteria, even within host tissues, is temperature. Temperature affects the multiplication rate of E. amylovora in culture, and it also affects the intensity of fire blight infections $(3,14,18)$. The optimal temperature for $E$. amylovora development is $28^{\circ} \mathrm{C}$, but it can

Table 1. Effects of vigor and shoot growth of pear trees in autumn or spring on the proportion of expanded fire blight infections ${ }^{\mathrm{w}}$

\begin{tabular}{|c|c|c|c|c|c|c|}
\hline \multirow[b]{2}{*}{ Season } & \multirow[b]{2}{*}{ Experiment } & \multirow[b]{2}{*}{ Site } & \multirow{2}{*}{$\begin{array}{l}\text { Source of } \\
\text { infection }\end{array}$} & \multirow{2}{*}{$\begin{array}{l}\text { Shoot growth } \\
\text { of trees }^{x}\end{array}$} & \multicolumn{2}{|c|}{$\begin{array}{l}\text { Proportion expanded } \\
\text { infections }(\%)\end{array}$} \\
\hline & & & & & Low $^{\mathrm{y}}$ & High $^{y}$ \\
\hline \multirow[t]{4}{*}{ Spring } & 1999 & Shpheia & Natural & + & 0 & $14.2 * \mathrm{z}$ \\
\hline & & Shpheia & Artificial & + & 0 & 0 \\
\hline & 2002 & Shpheia & Natural & + & 0 & 3.0 \\
\hline & & Khula & Artificial & + & 0 & 0 \\
\hline \multirow{4}{*}{ Autumn } & 1999/00 & Shpheia & Artificial & - & $66.7 *$ & 4.7 \\
\hline & 2000/01 & Shpheia & Artificial & - & $50.0^{*}$ & 14.3 \\
\hline & $2001 / 02$ & Shpheia & Artificial & - & $78.5^{*}$ & 33.3 \\
\hline & $2001 / 02$ & Khula & Artificial & + & 0 & $66.6^{*}$ \\
\hline
\end{tabular}

${ }^{\mathrm{w}}$ Expanded infection: infections that had progressed from site of infection to four or more consecutive perennial branches and reached main limbs or trunk.

${ }^{\mathrm{x}}+$, trees with actively growing shoots; - , trees with no active shoot growth.

y Low vigor: succulent annual shoots did not develop at most terminal branches and the annual shoots that did develop were short $(<10 \mathrm{~cm})$ and thin $(<5 \mathrm{~mm})$. High vigor: trees that had numerous, long $(>30 \mathrm{~cm})$ and thick $(>10 \mathrm{~mm})$ succulent sprouting annual shoots at most terminal branches.

${ }^{\mathrm{z}}$ Asterisks indicate significant difference $(P \leq 0.05)$ in proportion of expanded infections between trees with limited and trees with high vigor, for each row, as determined by a $\chi^{2}$ test. tions. Following natural spring infection of low-vigor trees at three of our study sites, symptom progression in perennial branches was $\leq 10 \mathrm{~cm}$ in 100,76 , and $94 \%$ of the trees. In high-vigor trees, on the other hand, fire blight symptoms had progressed $>30 \mathrm{~cm}$ in 25,76 , and $50 \%$ of trees in the respective orchards (unpublished data). Comparison of the frequency distribution of symptom progression between trees with low vigor and trees with high vigor revealed that they were significantly different at $P \leq 0.05$ (as determined by a $\chi^{2}$ test). In general, our data for spring infections were in line with these observations and dogmas. However, it was unexpected to find that trees which did not support active summer regrowth, and which has exhibited low vigor in the previous spring, would be more susceptible to autumn infections than trees that had exhibited high vigor in the spring. Similarly, it was not expected that symptom progression following spring infections ceased within 2 to 3 months (by mid-May to mid-July) and that such symptoms were less dangerous than those that resulted from autumn infections. The latter continued to progress during the winter for at least 4 to 6 months.

Data in the literature on relationships between phenological stage of the host and extent of fire blight progression in perennial branches are incomplete and difficult to interrelate. Biggs (2) inoculated apple shoots (cv. Jonathan) from May to August at 2-week intervals and found that the earlier in the season the inoculation was carried out, the longer the canker. Deckers and Daemen (6) noted that fire blight infections begun in August on pear and apple blossoms borne by regrowth shoots resulted in tree death within 4 weeks. On the other hand, Beer and Norelli (1) found that inoculation of young, nursery-grown pear and apple trees in midseason (July) produced cankers with determinate margins (i.e., cankers that did not continue to expand), whereas those inoculated later in the season (September) produced mostly cankers with indeterminate margins (i.e., expanding cankers). Although environmental conditions in the sites where these experiments were conducted differed from those prevailing in Israel, these observations are in line with those in the present study.

In order to understand the factors governing the progression of fire blight in perennial tissues, it is essential to consider the time at which marked changes in symptom progression rate occurred. Following spring infections, symptom progression had ceased during mid-May to mid-July. Following autumn infections, the symptom progression rate increased in mid-January to late February, from 0.1 to $0.3 \mathrm{~cm} /$ day to 1.5 to $2.5 \mathrm{~cm} /$ day. What caused these marked shifts? Both periods are characterized by considerable changes in host phenology and physiology: during midMay to mid-July, vegetative growth termi- 
nates and fruit development begins. In mid-January to late February, pear trees in Israel initiate the physiological process that leads to termination of dormancy and beginning of budding. These facts, together with the observations that tree vigor and shoot growth affected susceptibility to $E$. amylovora, suggest that factors related to host phenology and physiology, rather than factors related to the pathogen or to environmental influences, govern the extent, rate, and duration of fire blight progression in perennial pear branches in Israel.

The process by which pear tree physiology affects $E$. amylovora progression in perennial branches is not fully understood and is currently under investigation. Nevertheless, several practical implications may arise from our observations. Currently, Israeli pear growers are advised to cut and remove infected tissues as soon as they observe them, but the results of the present study imply that these recommendations should be revised. For example, if spring infections on trees that exhibit low vigor are likely to remain restricted to the blossom clusters and spurs, it is not necessary to prune these infections (15). Furthermore, our results are in line with previous findings that application of growth regulators such as prohexadione-Ca reduces the susceptibility of pear and apple trees to E. amylovora $(7,11)$. The questions of how management of spring shoot growth affects late-summer regrowth and the suscepti-
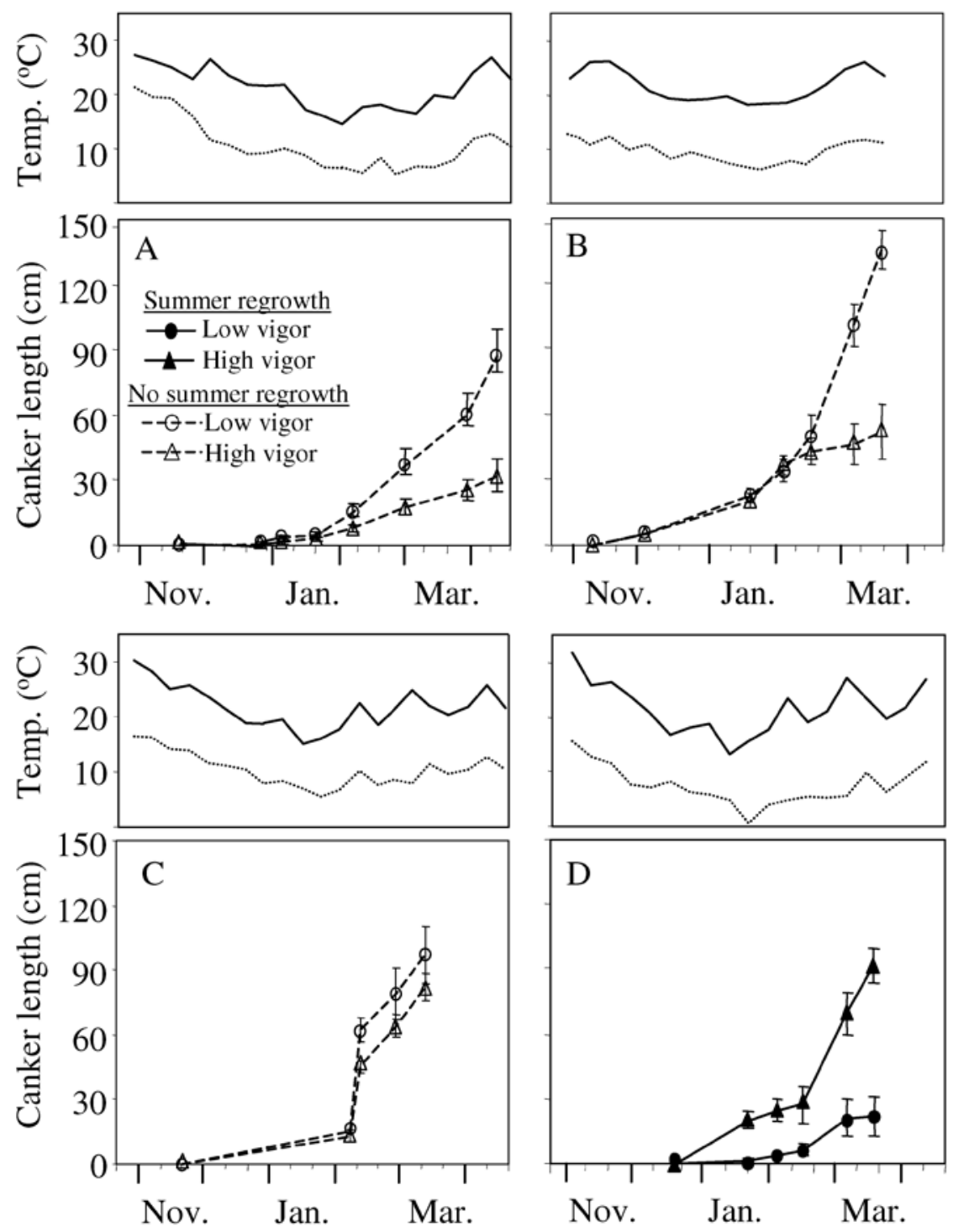

Fig. 2. Effects of tree vigor and sprouting activity of pear trees on the progression of fire blight symptoms in perennial branches following artificial autumn infections in Shpheia in 1999 to 2000 (A), 2000 to 2001 (B), and 2001 to 2002 (C), and Khula in 2001 to 2002 (D). On trees with low vigor, succulent annual shoots did not develop at most terminal branches and the annual shoots that did develop were short $(<10 \mathrm{~cm})$ and thin $(<5 \mathrm{~mm})$. Trees with high vigor had numerous, long ( $>30$ $\mathrm{cm})$, thick $(>10 \mathrm{~mm})$, succulent sprouting annual shoots at most terminal branches. Vertical bars represent the standard error for each sampling date. Ten-day mean temperatures for the experimental periods are shown. Solid lines: maximum daily temperatures; dotted lines: minimum daily temperatures. bility of trees to autumn infections remain to be answered.

The results of our present study imply that autumn infections play a substantial role in fire blight epidemiology in Israel. Because of the long period of progression in the perennial branches, many autumn infections invade the main limbs and trunks of trees and cause significant economic losses. Cankers that result from these infections are hard to detect, and sometimes become active only early in the spring. The surviving cankers may serve as a source of inoculum for subsequent spring infections when it is already too late for sanitation. The conclusion is that autumn infections should be prevented by all means. This can be done by: (i) proper maintenance of the orchard with regard to irrigation and fertilization, in order to prevent the occurrence of autumn blooming; (ii) mechanical or chemical removal of autumn blossoms, if they occur (24); and (iii) frequent, strict inspection of orchards in autumn, and eradication of infected tissues as soon as they are observed. As blooming in autumn is not uniform and may continue for a long time, application of preventive bactericide sprays is not recommended. All these measures are currently being implemented by pear growers in Israel, and the relative significance of autumn infections has been markedly reduced in recent years.

\section{ACKNOWLEDGMENTS}

We thank S. Manulis for providing E. amylovora strains for inoculations, and $\mathrm{H}$. Shwartz and H. Vintal for their assistance. This research was supported in part by the chief scientist of the Israeli Ministry of Agriculture and Rural Development, and by the Fruit Tree Council. Contribution number 522/02 from the Agricultural Research Organization, the Volcani Center, Bet Dagan 50250, Israel.

\section{LITERATURE CITED}

1. Beer, S. V., and Norelli, J. L. 1977. Fire blight epidemiology: Factors affecting release of Erwinia amylovora by cankers. Phytopathology 67:1119-1125.

2. Biggs, A. R. 1994. Characteristics of fire blight cankers following shoot inoculations of three apple cultivars. HortScience 29:795797.

3. Billing, E. 1974. The effect of temperature on the growth of the fire blight pathogen, $E r$ winia amylovora. J. Appl. Bacteriol. 37:643648 .

4. Blake, M. A. 1934. The relation of growth status of apple and pear trees to injury by fire blight. N.J. State Hortic. Soc. News 15:618619.

5. Crosse, J. E., Goodman, R. N., and Shaffer, W. H., Jr. 1972. Leaf damage as predisposing factor in the infection of apple shoots by Erwinia amylovora. Phytopathology 62:176182.

6. Deckers, T., and Daemen, E. 1999. Determining factors reducing the host susceptibility of fruit trees for fire blight infections. Acta Hortic. 489:483-489.

7. Fernando, W. G. D., and Jones, A. L. 1999. Prohexodione calcium, a tool for reducing secondary fire blight infection. Acta Hortic. 489:597-599.

8. Hildebrand, E. M. 1937. The blossom blight 
phase of fire blight and methods of control. Cornell Univ. Agric. Exp. Stn. Memoir 207, Ithaca, NY.

9. Manulis, S., Kleitman, F., Dror, O., David, I., Zilberstaine, M., and Shabi, E. 1998. Distribution of streptomycin-resistant strains of Erwinia amylovora and occurrence of blossom blight in the autumn. Phytoparasitica 26:223-230.

10. Miller, P. W., and Schroth, M. N. 1972. Monitoring the epiphytic population of Erwinia amylovora on pear with selective medium. Phytopathology 62:1175-1182.

11. Momol, M. T., Ugine, J. D., Norelli, J. L., and Aldwinckle, H. S. 1999. The effect of prohexadione calcium, SAR inducers and calcium, on the control of shoot blight caused by Erwinia amylovora on apple. Acta Hortic. 489:601-605.

12. Nixon, E. L. 1927. The migration of Bacillus amylovorus in apple tissues and its effect on the host cells. Pa. Agric. Exp. Stn. Bull. 212.

13. Rosen, H. R. 1929. The life history of the fire blight pathogen, Bacillus amylovorus, as related to the means of over wintering and dissemination. Ark. Agric. Exp. Stn. Bull. 283

14. Schouten, H. J. 1989. A possible role for the swelling of extracellular polysaccharide of Erwinia amylovora at increasing water potential. Neth. J. Plant Pathol. 95:169-174.

15. Shtienberg, D., Zilberstaine, M., Oppenheim, D., Levi, S., Shwartz, H., and Kritzman, G. 2003. New considerations for pruning in management of fire blight in pears. Plant Dis. 87:1083-1088

16. Steiner, P. W. 1990. Predicting canker, shoot and trauma blight phases of apple fire blight epidemics using the Maryblyt model. Acta Hortic. 273:149-158.

17. Suleman, P. 1992. Factors affecting fire blight symptom development in vegetative tissues of apple infected by Erwinia amylovora (Burr.) Winslow et al. Ph.D. thesis. University of Maryland, College Park.

18. Thomson, V. S. 2000. Epidemiology of fire blight. Pages 9-36 in: Fire Blight: The Dis- ease and its Causative Agent, Erwinia amylovora. J. L. Vanneste, ed. CABI Publishing, Oxon, UK.

19. Tullis, E. C. 1929. Studies on the over wintering and modes of infection of the fire blight organism. Mich. Agric. Exp. Stn. Bull. 97.

20. van der Zwet, T. B. 1969. Study of fire blight cankers and associated bacteria in pear. Phytopathology 59:607-613.

21. van der Zwet, T. B., and Beer, S. V. 1995. Fire blight - Its nature, prevention and control U.S. Dep. Agric. Bull. 631

22. van der Zwet, T. B., and Keil, H. L. 1979. Fire blight: A bacterial disease of Rosaceous plants. U.S. Dep. Agric. Handb. 510.

23. van der Zwet, T. B., Zoller, B. G., and Thomson, S. V. 1988. Controlling fire blight of pea and apple by accurate prediction of the blossom blight phase. Plant Dis. 72:464-472.

24. Zilberstaine, M. Herzog, Z., and Doron, I. 1999. Removal of off season flowers in order to avoid E. amylovaora infection in pears. Acta Hortic. 489:625-628. 